\title{
Carboniferous trace fossils from Vélez-Málaga (Maláguide Complex, Betic Cordillera, SE Spain)
}

\author{
Eduardo J. MAYORAL ${ }^{1 *}$, José A. GÁMEZ VINTANED', José B. DIEZ³ \& Eladio LIÑÁN ${ }^{4}$
}

${ }^{1}$ Departamento de Ciencias de la Tierra y Centro de Investigación Científico Tecnológico, Facultad de Ciencias Experimentales, Campus de El Carmen, Universidad de Huelva, Avda. 3 de marzo s/n, 21071 Huelva, Spain; mayoral@uhu.es

${ }^{2}$ Department of Geosciences, Faculty of Sciences \& Information Technology, Universiti Teknologi PETRONAS (UTP), Bandar Seri Iskandar, 31750 Tronoh, Perak Darul Ridzuan, Malaysia; jose.gamez@utp.edu.my

${ }^{3}$ Departamento de Geociencias Marinas y Ordenación del Territorio, Universidad de Vigo, Campus Lagoas-Marcosende, 36200 Vigo, Spain; jbdiezf@gmail.com

${ }^{4}$ Departamento de Ciencias de la Tierra-IUCA, Universidad de Zaragoza, 50009 Zaragoza, Spain; linan@unizar.es

* Corresponding author

Mayoral, E.J., Gámez Vintaned, J.A., Diez, J.B. \& Liñán, E. 2018. Carboniferous trace fossils from Vélez-Málaga (Maláguide Complex, Betic Cordillera, SE Spain). [Icnofósiles del Carbonífero del Complejo Maláguide en Vélez-Málaga (Cordillera Bética, SE de España)]. Spanish Journal of Palaeontology, 33 (1), 89-104.

\section{ABSTRACT}

A stratigraphic section of the Maláguide Complex cropping out at the easternmost part of the Málaga Province (SE Spain) is studied. Previous palaeontological data were unknown in this area. A lower stratigraphic Interval I has yielded fossil Equisetales plants, probable ferns and centrimetric xylic fragments at several centimetric slate levels interspersed between the dominating micaceous, brown, medium to coarsegrained sandstone. The ichnofossil Planolites annularis occurs at numerous levels of Interval I. An upper stratigraphic Interval II has yielded two particularly rich ichnoassemblages at its lower part, which are the main object of our study. The upper ichnoassemblage also contains skeletal remains of metazoans or moulds, namely remains of crinoid stalks, trilobites, and bivalves, as well as probable microbial mats. The two main ichnoassemblages belong to the Cruziana ichnofacies and have provided, overall, eleven ichnogenera including fourteen ichnotaxa: Bergaueria aff. perata, Dactyloidites aff. cabanasi, Diplichnites ichnosp. A, Diplichnites ichnosp. B, Dolopichnus ichnosp. indet., Monocraterion ichnosp. indet.,

\section{RESUMEN}

En este trabajo se estudia una sección estratigráfica en el Complejo Maláguide que aflora en el extremo más oriental de la provincia de Málaga (SE de España), que estaba falto de datos paleontológicos previos. En la sucesión se han diferenciado dos intervalos estratigráficos. El inferior (Intervalo I) ha proporcionado restos fósiles de plantas equisetales, de probables helechos y fragmentos xílicos centimétricos en varios niveles centimétricos de pizarras que se encuentran intercalados entre las areniscas pardas micáceas, de grano medio a grueso, que dominan en esta parte de la sucesión. El icnofósil Planolites annularis está presente en numerosos niveles del Intervalo I. En el suprayacente Intervalo II se encuentran los dos principales cortejos (contenidos) icnológicos que son objeto de este estudio, en dos niveles situados en su parte inferior. El segundo de ellos en orden estratigráfico ha proporcionado también restos de fósiles esqueléticos y moldes de metazoos, como artejos de tallos de crinoideos, trilobites y bivalvos, así como también probables tapices microbianos. Los dos principales cortejos icnológicos 
Monomorphichnus aff. lineatus, Monomorphichnus ichnosp. indet., Palaeophycus tubularis, Planolites annularis, aff. Psammichnites, Rusophycus ichnosp. A, Rusophycus ichnosp. B. and aff. Treptichnus. It is concluded that 1) the study stratigraphic succession belongs to the upper member of the Almogía Formation, post-Visean Carboniferous in age, and 2) it was deposited under palaeoenvironments that evolved from proximal shallow marine (nearshore; Interval I) up to shallow sublittoral (i.e., infralittoral) in a siliciclastic continental shelf (Interval II).

Keywords: Trace fossils, systematic palaeoichnology, Almogía Formation, lower Carboniferous, Maláguide Complex. mencionados pertenecen a la icnofacies de Cruziana y han proporcionado, en su conjunto, once icnogéneros que incluyen catorce icnotaxones: Bergaueria aff. perata, Dactyloidites aff. cabanasi, Diplichnites ichnosp. A, Diplichnites ichnosp. B, Dolopichnus ichnosp. indet., Monocraterion ichnosp. indet., Monomorphichnus aff. lineatus, Monomorphichnus ichnosp. indet., Palaeophycus tubularis, Planolites annularis, aff. Psammichnites, Rusophycus ichnosp. A, Rusophycus ichnosp. B. y aff. Treptichnus. Se concluye que los materiales estudiados deben pertenecer al miembro superior de la Formación Almogía (de edad Carbonífero post-Viseense), y que fueron depositados en paleoambientes que evolucionaron desde marinos someros proximales (costeros; Intervalo I) hasta medios sublitorales someros (infralitorales) en una plataforma continental siliciclástica (Intervalo II).

Palabras clave: Pistas fósiles, paleoicnología sistemática, Formación Almogía, Carbonífero inferior, Complejo Maláguide.

\section{INTRODUCTION AND REGIONAL LITHOSTRATIGRAPHY}

The Maláguide Complex (Blumenthal, 1927; Durand Delga, 1963) is the upper tectonostratigraphic unit of the Internal Zones of the Betic Mountain Range. It stretches mainly through the province of Málaga (SE Spain), from Estepona to Vélez-Málaga, where it is put in contact with the Benthomix Unit (Alonso Chaves \& Orozco, 2012), a unit located at the easternmost part of the Alpujárride Complex (Fig. 1)

Between the Maláguide and the Alpujárride complexes, a transitional unit, the so-called Benamocarra Unit, has been defined in the region of the Axarquía. According to Martín-Algarra (2004), this unit should be included within the Maláguide Complex due to its petrological characteristics.

The Paleozoic basement of the Maláguide Complex has a mainly turbiditic origin. It is composed of the following lithostratigraphic units, in a stratigraphic order: Morales Formation, Santi Petri Formation, Falcoña Formation, Almogía Formation and Marbella Conglomerate (MartínAlgarra et al., 2004; Serrano \& Guerra-Merchán, 2004). The Morales Formation (Mon, 1971) is a slate-greywackic succession that shows lower-grade metamorphism towards deeper levels; a metamorphic grade is also detected near important tectonic accidents. The Morales Formation is composed of shale and schists that alternate with brown quartz feldspathic levels, more competent, where original sedimentary structures can be observed. Discontinuous, decimetric and fissural fillings of white quartzite are also observed. In the deepest, shaly levels there is a dark mottling formed by graphitic aggregates of sericite with relicts of metamorphic minerals such as andalusite and garnet
(Tubía, 1985). This metamorphism fades into the upper part, where reddish slates appear, metric to decametric horizons of stretched, and crushed stones of quartzite, as well as gneiss and limestone, are observed. The Morales Formation belongs to the Benamocarra tectonic unit, as Ruiz Cruz (1997) and Ruiz Cruz \& Nieto (2002) already indicated. In this regard, we have observed along the outcrops between Torre del Mar and Benamocarra, the presence of frequent discontinuous beds of white quartzite with graphitic mottling of sericite and numerous intrusions of basic, subvolcanic rocks (tholeiites) which become interspersed between the beds of sandstone, shale and schists. In the outcrops of the eastern wards Chirivel region (Almería Province), the upper part of the Morales Formation contains early Silurian conodonts, tentaculitids and tintinids (Soedonio, 1971), as well as early Silurian graptolites in similar levels from the Rif Cordillera. In consequence, the upper part of the Morales Formation is dated as Silurian, while the lower part is interpreted as Ordovician or even older (Serrano \& Guerra-Merchán, 2004).

The Santi Petri Formation consists of calcareous beds (named as "calizas alabeadas" facies). At the upper part, a several meters-thick pelitic succession, occasionally with pinkish colour tones, indicates a gradual transition into the Falcoña Formation. The latter shows a lower member, a dozen of meters-thick, composed of dark radiolarites deposited in centimetric beds enriched with silica originated from volcanic fluids (lidites or silexites). These rocks are usually intensely folded and transformed into quartzites at the majority of the outcrops; they contain Tournaisian radiolarians (O'Dogherty et al., 2000). The uppermost part of the Falcoña Formation is formed by micritic limestone bearing late Visean conodonts (Rodríguez-Cañero \& Guerra-Merchán, 1996). This 
episode of deep facies deposition, which is previous to the Culm facies, or Variscid synorogenic sedimentation, is also recognised in many other regions of Europe.

The Almogía Formation (Mon, 1971) lays unconformably above other pre-existing formations, from which it seems to have "collected" large rock blocks (olistoliths). In our opinion, this must record the beginning of the inversion of the basin. According to Mon (1971) and Martín-Algarra et al. (2004), there are 200-300 m of greywacke, conglomerate and slates of brown, green-yellowish and gray-bluish colours originated by turbiditic sedimentation. Nevertheless, characteristic trace fossils of the deep marine Nereites ichnofacies have not been reported. In the lower Retamares Member, conglomerate and greywacke predominate, with intercalations of slate and large limestone olistoliths (Herbig, 1983; Rodríguez Cañero, 1993). The siliciclastic levels contain brachiopods and traces of plants dragged to the seabed. The large limestone olistoliths contain Silurian and Devonian conodonts, which obviously derive from preexisting formations. Based on its stratigraphic position, the Almogía Formation is dated as post-Visean, lower Carboniferous (Martín-Algarra et al., 2004).
The Marbella Conglomerate (Blumenthal, 1949) is a polygenic conglomerate deposited above an erosive unconformity affecting other pre-existing formations, thus recording, in our opinion, an advanced phase in the inversion of the basin. It contains large blocks of sedimentary rocks, gneisses and granites. The limestone present is found to contain early and mid Carboniferous conodonts, corals, algae, fusulinids, bryozoans and corals (Herbig, 1984; Herbig \& Mamet, 1985); so that their most probable age is late Carboniferous (Serrano \& GuerraMerchán, 2004).

So far, no fossiliferous sites had been mentioned from the southeastern part of the Maláguide Complex, which includes the Axarquía of Málaga, and no palaeoichnological studies have been performed in the complex. Thus, the main goals of this work are: 1) Describing the first palaeoichnological assemblages found in the Paleozoic of the Maláguide Complex; 2) identifying the lithostratigraphic formation in which the ichnofossils are found; and 3) characterising the age of those stratigraphic levels. The study of the lithostratigraphic succession and other macrofossils found are useful tools to reach these

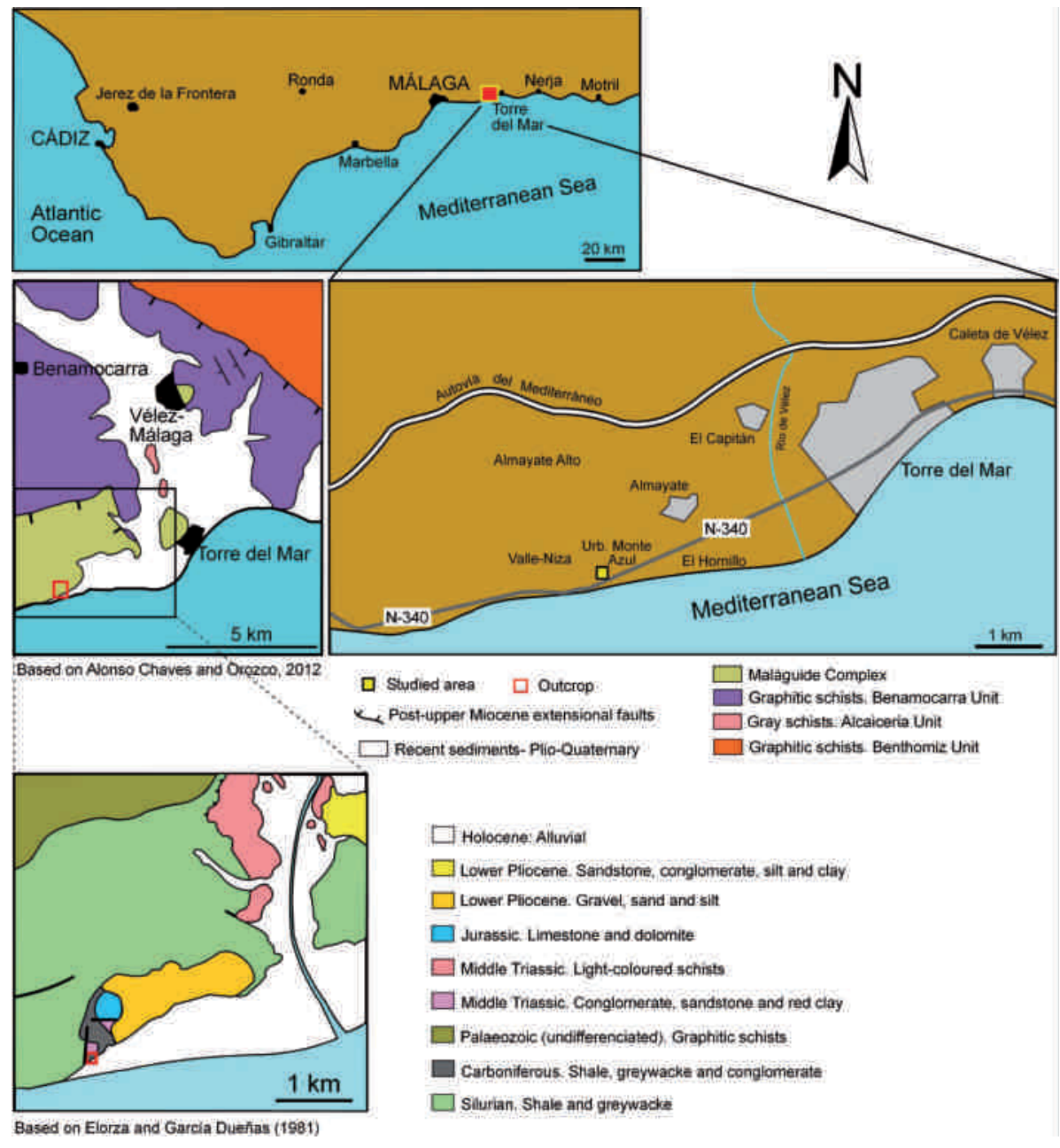

Figure 1. Geographical and geological sketches of the area and location of the studied outcrop. 
objectives, especially after having obtained negative results from the palynological samples recently studied.

\section{GEOGRAPHICAL AND GEOLOGICAL LOCATION}

The outcrop studied herein is located west of the locality of Almayate (Vélez-Málaga), between the village and the Monte Azul urbanisation (Fig. 1). The outcrop constitutes the easternmost exposure of the Maláguide Complex in the Málaga Province. It is limited to the northeast by a narrow fault band of Permo-Triassic materials, to the west by the Pliocene outcrop of Almayate village, and to the south by the recent coastal deposits (Fig. 1).

The 1:50,000 geological map of Vélez-Málaga does not record the outcrops of the different stratigraphic formations composing the Paleozoic basement of the Maláguide Complex; instead, it differentiates the outcrops by their geological age (Elorza \& García Dueñas, 1981). Based on the type of facies, these authors assigned the study outcrop to a part of a Carboniferous band located between two faults (Fig. 1).

\section{STRATIGRAPHY}

The studied section, named Vélez-Málaga 1 (VM-1), runs along the trench of an old railway, from the Monte Azul urbanisation up to the Pliocene outcrops near the village of Almayate (Fig. 2).
Beds are folded, with fold limbs dipping $35^{\circ}$ to $40^{\circ}$ across an $\mathrm{N} 030^{\circ} \mathrm{E}$ strike, depicting narrow metric folds, sometimes faulted, with frequent inverted bedding planes included in an apparently $50 \mathrm{~m}$-thick stratigraphic successions (Fig. 3).

The succession can be subdivided into two stratigraphic intervals separated by a fault. Levels with the ichnofossil Planolites annularis Walcott, 1890 are frequent in both intervals, occurring at the contact between sandstone beds and slate layers. On the other hand, as it has been already stated above, a detailed field sampling in search of palynomorph fossils yielded negative results at the laboratory.

The lower stratigraphic interval, Interval I, presents metric and decimetric beds of micaceous, brown sandstone bearing sparse microconglomerate levels at the lower part of the interval, in alternance with sporadic centimetric levels of gray and brown slate. The base of the lower interval presents sedimentary structures such as paleochannels, flute cast, laminations and cross-bedding, together with numerous fossil stems of Equisetidae plants, probable ferns and centimetric xylic fragments. Planolites annularis occurs at numerous levels.

The upper interval, Interval II, consists of an alternation of sandstone and slate, with sparse microconglomerate levels at its lower part (Fig. 3). It contains two particularly rich, diversified ichnoassemblages recorded at two different but close stratigraphic levels located at the lower part of Interval II. The lower ichnoassemblage is located $3.5 \mathrm{~m}$ above the base of Interval II, at the top bedding plane of a brownish, micaceous, and medium to coarsegrained sandstone. Slightly higher up in the stratigraphical succession, the upper ichnoassemblage is found, located

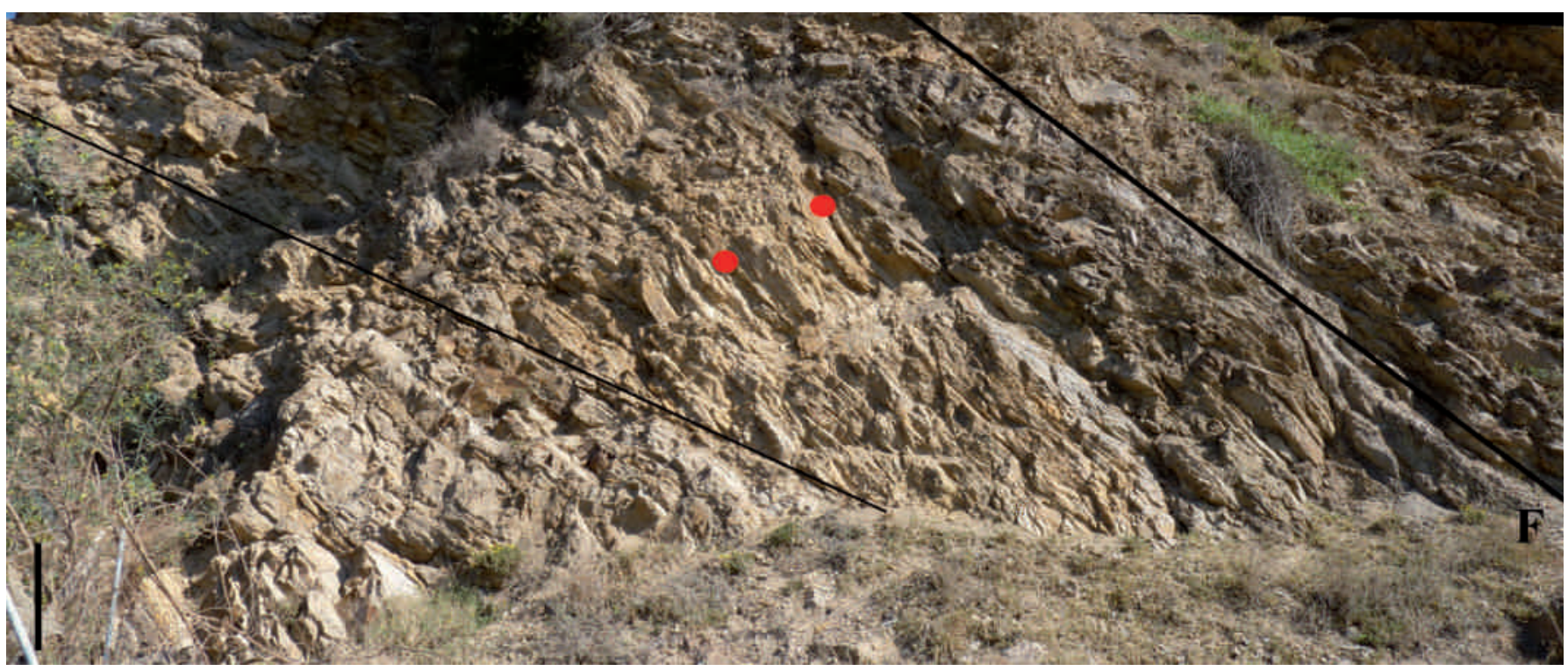

Figure 2. Appearance of the lower part of the upper stretch of the stratigraphic section Vélez-Málaga 1 (VM-1) with lying folds with flanks dipping $40^{\circ} \mathrm{E}$, and location of the two main beds bearing ichnotaxa (red points). F: fault. Scale bar $=1 \mathrm{~m}$. 


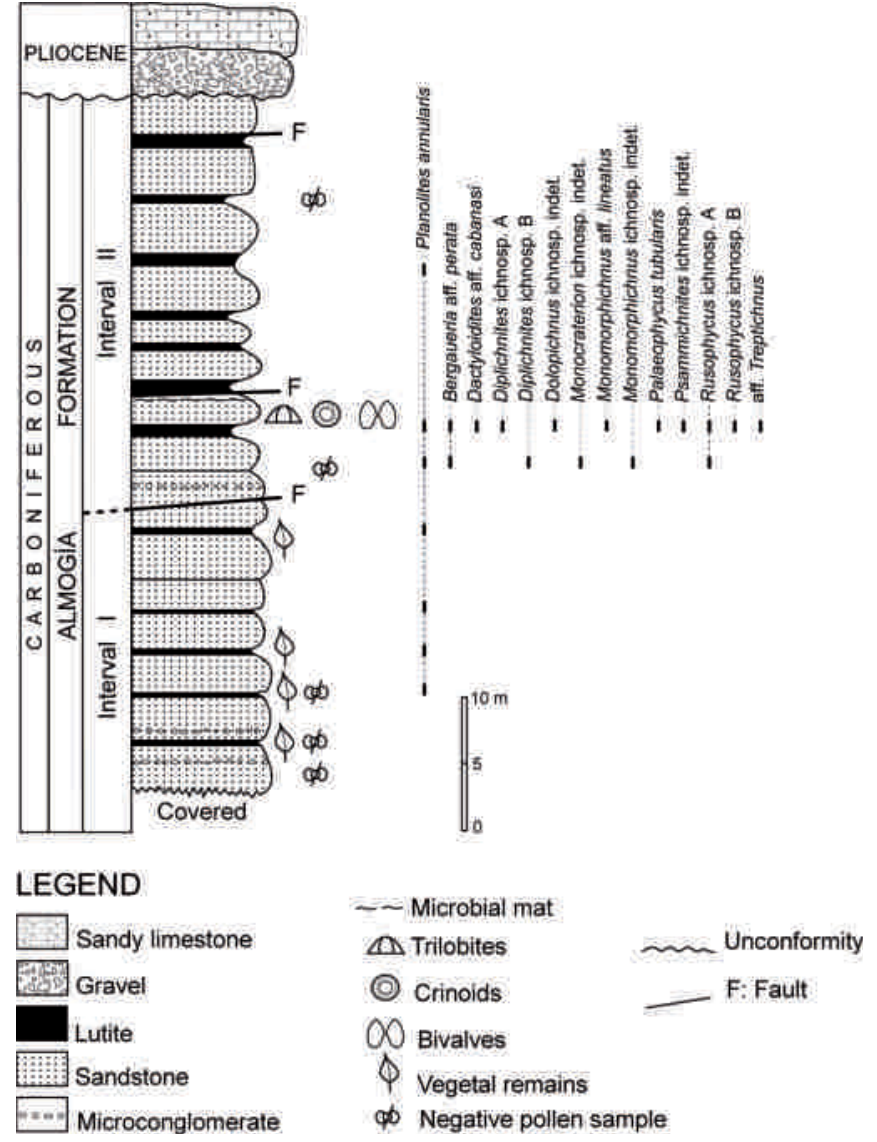

Figure 3. Idealised stratigraphic column of the Vélez-Málaga 1 section, showing the tentative location of ichnofossils and skeletal metazoan fossils.

$6.2 \mathrm{~m}$ above the base of Interval II. The ichnoassemblage occurs at the contact between a thin slate layer and the overlying sandstone bed. The horizon also contains arcoid bivalves, disarticulated crinoid stalks and trilobite remains (Fig. 4). It is worth noting the presence, at the same bedding plane, of a probable microbial mat. The mat appears at the bottom of the sandstone and seems to be covered by an interspersed, very thin layer of slate containing a few pebbles ranging from 8 to $13 \mathrm{~mm}$ in diameter.

The lithological and palaeontological features listed above allow us assigning, with a high degree of confidence, the study materials to the upper member of the Almogía Formation. Regarding the age of the study succession, it is necessarily stated, after the age interpretation of the formation given by Martín-Algarra et al. (2004), as post-Visean (Carboniferous). We have not found agediagnostic fossils, either body or trace fossils, as to make any improvement to this dating.

\section{SYSTEMATIC PALAEOICHNOLOGY}

Most of the material studied was left in the field, while several specimens that could be extracted are deposited at the Department of Earth Sciences of the University of Huelva (Spain) under the acronym VM-1.

Ichnogenus Bergaueria Prantl, 1946

Type ichnospecies Bergaueria perata Prantl, 1946

Bergaueria aff. perata Prantl, 1946

(Fig. 5a)

Material. Five specimens preserved in convex hyporelief (VM-1/01-05) in micaceous, medium to coarsegrained sandstone.

Description. Bergaueria somewhat deeper (from 2.3 to $5.9 \mathrm{~mm}$, average: $4.8 \mathrm{~mm}$ ) than wide (from 1.4 to $5 \mathrm{~mm}$, average: $3.2 \mathrm{~mm}$ ), vertical to oblique, with a very thin coating, walls of the burrow parallel and with a rounded lower part. Only one specimen shows a fine concentric ornamentation. Subcircular cross-section.

Interpretation and discussion. The material studied has been identified with a certain degree of uncertainty since it does not present the typical transverse constrictions or radial furrows (frequent features, although not diagnostic) or a slight central depression, which are usually characteristic of this ichnospecies.

Probably, some of these features do not appear or are not preserved given that they are specimens of fairly small size.

Berganeria perata has been interpreted as dwelling structures produced by sea anemones, micropredators (Prantl, 1946; Alpert, 1973).

Ichnogenus Dactyloidites Hall, 1886

Type ichnospecies Dactyloidites bulbosus Hall, 1886

Dactyloidites aff. cabanasi (Meléndez in Cabanás, 1966) (Figs 5b-5e)

Material. Two specimens preserved as full reliefs (VM$1 / 06 ; 08)$, and another one as concave hyporelief but with the central shaft preserved as full relief (VM-1/07) from micaceous, medium to coarse-grained sandstone.

Description. Rosette-shaped burrow system composed of four horizontal, subpetaloid burrows radiating from a central, vertical shaft. Horizontal burrows show a vertical, retrusive spreite. The two full relief specimens are mostly 


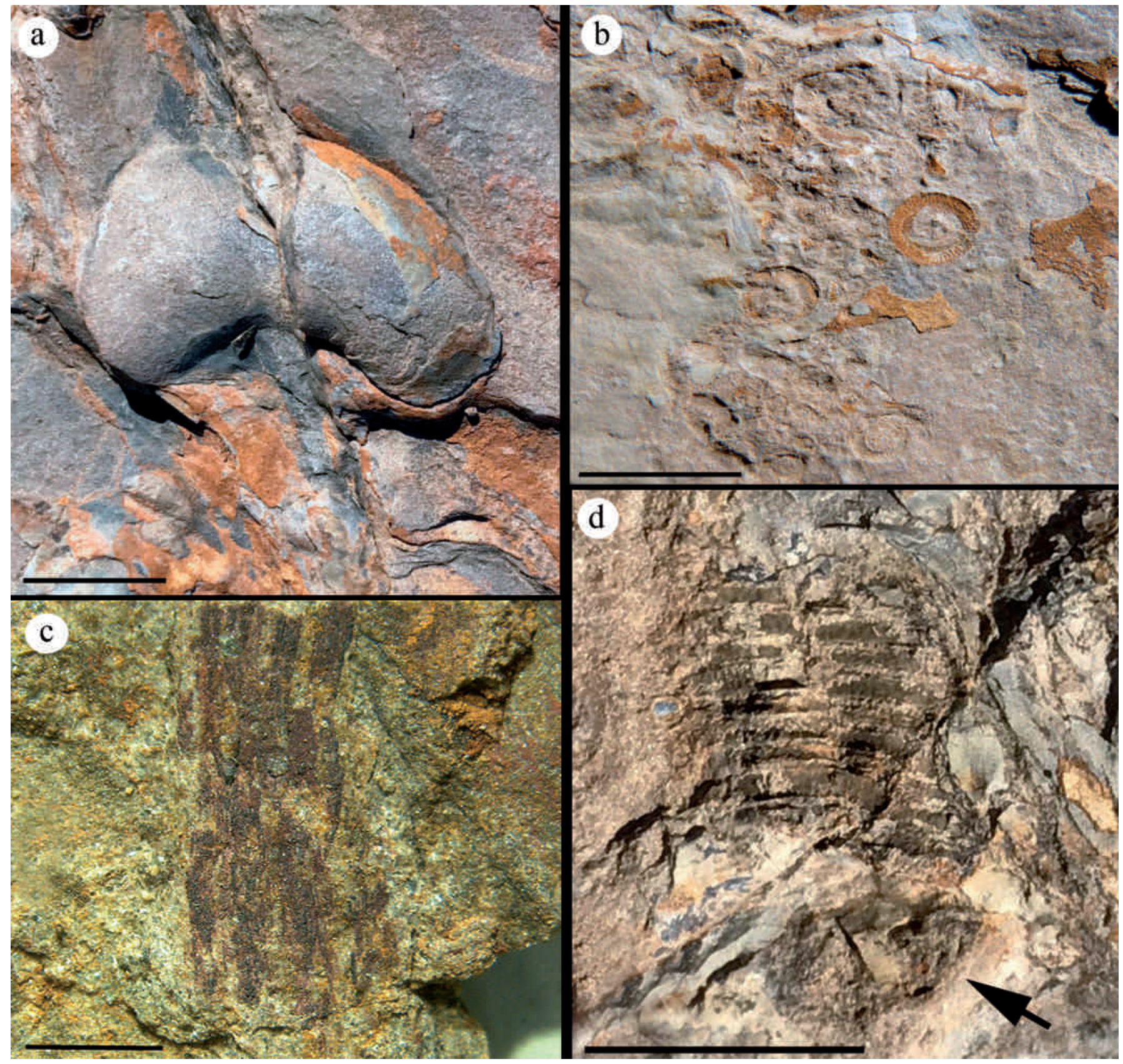

Figure 4. Fossils of skeletal metazoans. a) Internal mould of an articulated bivalve of the order Arcoida. b) Crinoid stalk plates. c) Equisetal remains from Interval I. d) Trilobite moult showing a poorly preserved pigidium (black arrow). Scale bars $=1$ $\mathrm{cm}$, except for (c) where scale bar is $1 \mathrm{~mm}$.

irregular in shape, showing an elongation axis overall. Dimensions of the whole trace are 21-27 mm x 34-46 mm. Radial burrows range in width from 8 to $10 \mathrm{~mm}$, while length varies, according to the degree of elongation, from $6.3-9 \mathrm{~mm}$ to $10-18 \mathrm{~mm}$.

The retrusive spreite is barely visible in a single specimen (Figs 5c, 5d), defined by a weak step that would mark the position of the burrow in its upward displacement. The central shaft is only clearly visible in specimen VM1/07 (Figs 5c, 5d), with a diameter of $4 \mathrm{~mm}$, while it is practically hidden in specimen VM-1/06, where a small depression of about $2 \mathrm{~mm}$ in diameter is recognised that would indicate the position of the shaft (Fig. 5b).

Interpretation and discussion. Our specimens differ from the ichnospecies $D$. cabanasi by the lack of the fine concave ridges that usually appear in the lobes of the unweathered specimens and the longitudinal, narrow grooves that run along the base of the radial burrows. The two elongated specimens also differ in their lack of radial symmetry. 
In some cases, our specimens appear in the proximity to small, scarce and scattered faecal pellets (Fig. 5e), a fact that has also been observed in some specimens of $D$. cabanasi from the lower Cambrian of Sierra de Córdoba (Gámez Vintaned et al., 2006).

Dactyloidites has been interpreted as feeding structures (fodinichnia) produced by mud-eater organisms feeding on nutrient-rich, soft substrates (Gibert et al., 1995; Agirrezabala \& Gibert, 2004). The existence of a retrusive spreite would be indicative of a sedimentary context of aggradation where sedimentation would be slow, although continuous, in shallow sublittoral conditions of moderate energy (Gámez Vintaned et al., 2006).

\section{Ichnogenus Diplichnites Dawson, 1873}

Type ichnospecies Diplichnites aenigma Dawson, 1873

\section{Diplichnites ichnosp. A}

(Fig. 5f)

Material. One specimen (VM-1/09) preserved as concave epirelief in micaceous, medium to coarse-grained sandstone.

Description. Incomplete trackway composed of two parallel rows of footprints; with a length of $53 \mathrm{~mm}$ and a width of $6.8 \mathrm{~mm}$. Individual impressions have a length of 1-1.5 $\mathrm{mm}$ and a width of $0.6 \mathrm{~mm}$. The distance between individual footprints varies between 9.7 and $13.8 \mathrm{~mm}$, along the direction of advance.

Interpretation and discussion. Trackway (repichnion) composed of footprints produced by trilobites when walking on the seabed (Fillion \& Pickerill, 1990).

\section{Diplichnites ichnosp. B}

(Fig. 6a)

Material. One specimen (VM-1/10) preserved as concave epirelief in micaceous, medium to coarse-grained sandstone.

Description. Incomplete trackway composed of two slightly convergent, rows of footprints, with a length of $12 \mathrm{~mm}$ and a width from 12.6 to $13 \mathrm{~mm}$. Individual footprints have a length of $0.6-1.5 \mathrm{~mm}$ and a width of 0.3 $\mathrm{mm}$. The distance between individual impressions along the direction of advance varies between 1.5 and $2.1 \mathrm{~mm}$.

Interpretation and discussion. Trackway (repichnion) produced by trilobites (Gámez Vintaned et al., 2006) of much smaller size than in the previous case (Diplichnites ichnosp. A). It appears associated to other traces left by trilobites while raking the substrate with the locomotory branches of their appendages (Monomorphichnus ichnosp. indet.), as it has been classically pointed out by Crimes (1970) and Crimes et al. (1977).

\section{Ichnogenus Dolopichnus Alpert \& Moore, 1975}

Type ichnospecies Dolopichnus gulosus Alpert \& Moore, 1975

\section{Dolopichnus ichnosp. indet.}

(Figs 6b-6c)

Material. Two specimens preserved in full relief(VM1/11-12) in micaceous, medium-grained sandstone.

Description. Vertical to slightly inclined burrow with subcircular (Fig. 6b; VM-1/12) to oval section (Fig. 6c; VM-1/11). This variation is the result of the intersection of the burrow, having either a vertical or an inclined axis, with the bedding plane. In the specimen VM-1/11, the central core has a diameter of $9 \mathrm{~mm}$ with a wall having an average thickness of $1.5 \mathrm{~mm}$. The total diameter of the structure is $17.5 \mathrm{~mm}$. The other specimen (VM-1/12) only presents the bulbous, basal extension of the nucleus, with a width of $10.3 \times 12.6 \mathrm{~mm}$.

These sections do not allow to properly observe the characteristics of the walls, although they are probably smooth and without ornaments. We cannot estimate either the length or the height of the burrow, which is usually four times the diameter.

Interpretation and discussion. The nucleus is interpreted as the room chamber of a sea anemone, a micropredator, resulting from the movement of the organism and the consequent displacement of the sediment towards the sides (Alpert \& Moore, 1975). The undifferentiated extension in which the burrow ends would be interpreted as the position of the physa that expands when the organism retracts into the burrow (Ansell \& Trueman, 1968).

Ichnogenus Monocraterion Torell, 1870

Type ichnospecies Monocraterion tentaculatum Hall, 1847

Monocraterion ichnosp. indet.

(Fig. 6d)

Material. Two specimens (VM-1/13-14) preserved as concave epirelief in coarse-grained sandstones. 


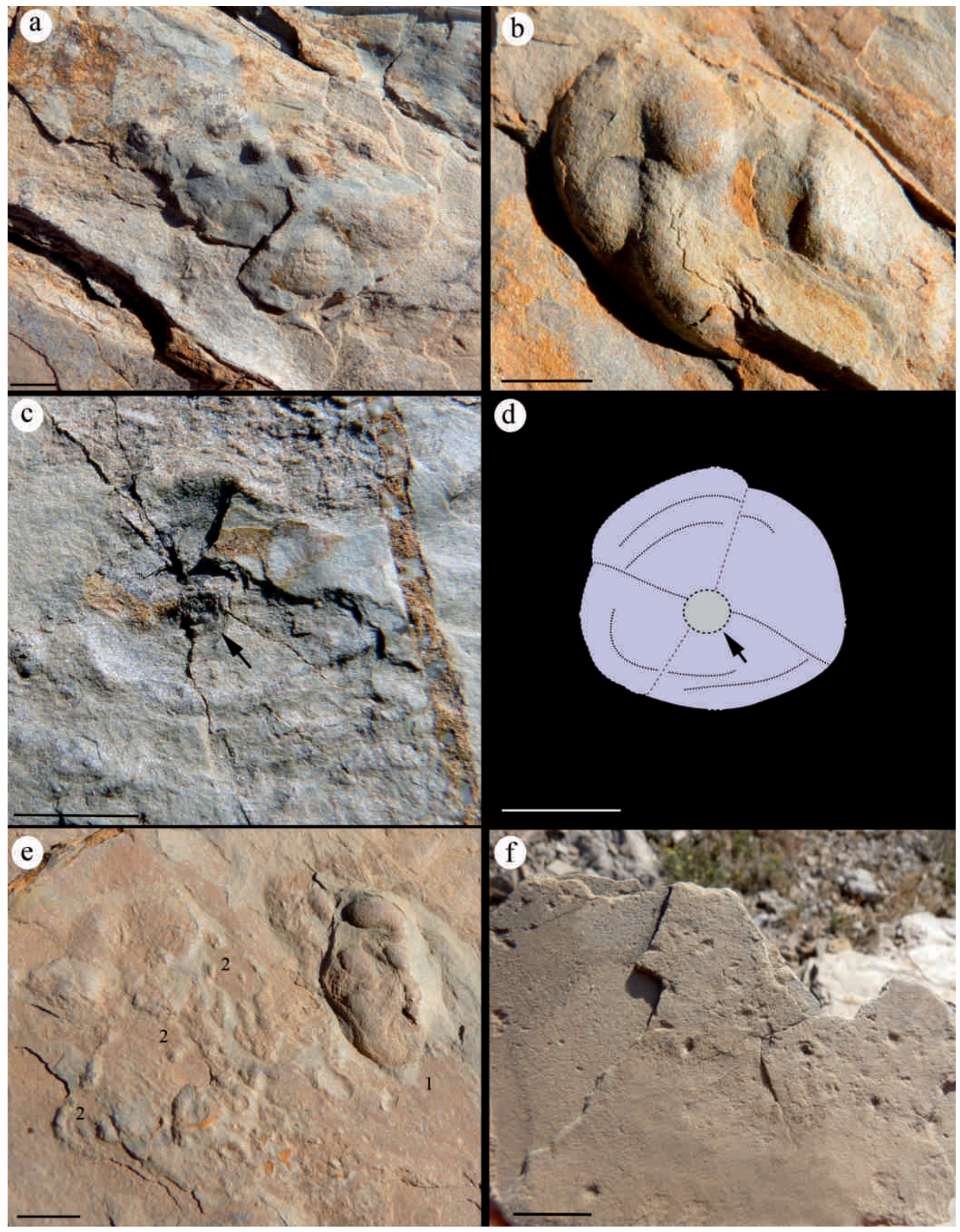

Figure 5. Ichnofossils. a) Bergaueria aff. perata Prantl, 1946. b-e) Dactyloidites aff. cabanasi (Meléndez in Cabanás, 1966). Black arrows in (c) and (d) point to the central shaft of the trace. (e) Number 1 indicates $D$. aff. cabanasi, and number 2 indicates pelletoidal faecal material. f) Diplichnites ichnosp. A. All scale bars $=1 \mathrm{~cm}$. 
Description. Conical, vertical structures with a diameter, which varies between 4.7 and $12.8 \mathrm{~mm}$, and a depth between 3.5 and $7 \mathrm{~mm}$. The lower end has a truncated apical termination. Inside the wall, it is present a thin concentric striation, which is repeated at intervals of 1 to $2 \mathrm{~mm}$.

Interpretation and discussion. This structure has been interpreted as a domichnion produced by a wide variety of organisms, mostly marine vermiform annelids, in the pursuit of either food particles in suspension, filter feeding, or organic detritus near the burrow opening (Crimes, 1970; Frey \& Howard, 1985).

\section{Ichnogenus Monomorphichnus Crimes, 1970}

Type ichnospecies Monomorphichnus bilinearis Crimes, 1970

\section{Monomorphichnus aff. lineatus Crimes, Legg, Marcos \& Arboleya, 1977}

(Fig. 6e)

Material. One specimen (VM-1/15) preserved as a convex hyporelief in micaceous, coarse-grained sandstone.

Description. A set consisting of a dozen of raking marks that cover an area of $33 \times 43 \mathrm{~mm}$. The marks, slightly deep, are straight to gently sigmoidal, with a length that varies from 1.2 to $21 \mathrm{~mm}$ ( $7 \mathrm{~mm}$ in average), and a width between 0.15 and $0.6 \mathrm{~mm}$.

Interpretation and discussion. Our trace differs from the ichnospecies $M$. lineatus in that the raking marks are not so sigmoidal and they do not show lateral repetition, the size being also much smaller. Our specimen may furthermore be distinguished from M. multilineatus Alpert, 1976 in that it presents the marks (ridges) associated by pairs. In addition, the central ridges are deeper than the ones closer to the extremes.

This ichnogenus is interpreted as sets of raking marks made by mobile benthic organisms (trilobitomorph arthropods) on the sea floor, in order of either gaining, or recovering, stability after the action of currents, or executing a combined action of grazing and swimming on the sea bottom surface (Crimes, 1970; Crimes et al., 1977).

\section{Monomorphichnus ichnosp. indet.}

(Fig. 6a)

Material. One specimen (VM-1/16) preserved as concave epirelief in micaceous, medium to coarse-grained sandstone.

Description. An isolated and incomplete set (VM-1/16) of three furrows aligned in parallel, with a length of 2.1 to $6 \mathrm{~mm}$ and a width of $0.6-0.9 \mathrm{~mm}$.
Interpretation and discussion. These raking marks appear on the same bedding plane and close to Diplichnites ichnosp. B. Although they are very close to each other, they do not cross.

Ichnogenus Palaeophycus Hall, 1847

Type ichnospecies Palaeophycus tubularis Hall, 1847

Palaeophycus tubularis Hall, 1847

(Fig. 6e)

Material. One specimen (VM-1/17) preserved as full relief in micaceous, medium- grained sandstone.

Description. Cylindrical, almost straight burrow with a length of $125 \mathrm{~mm}$ and a fairly uniform width, varying between 2.5 and $3.3 \mathrm{~mm}$. It shows a very thin coating. At some points of the trace, a very weak and discontinuous striation is also observed.

Interpretation and discussion. Palaeophycus are interpreted as domichnia burrows which were kept open and stable thanks to the reinforcing effect of the observed wall coating. Once abandoned, they were passively filled through their open ends with a material that may differ from the one of the surrounding rock matrix. This trace was most likely produced by a predator, although a filterfeeder organism cannot be excluded either (Pemberton \& Frey, 1982; Fillion \& Pickerill, 1990).

Ichnogenus Planolites Nicholson, 1873

Type ichnospecies Planolites vulgaris Nicholson \& Hinde, 1875

\section{Planolites annularis Walcott, 1890}

(Fig. 6e)

Material. Two specimens (VM-1/18-19) preserved as full reliefs in micaceous, medium to coarse-grained sandstone.

Description. Simple, subcylindrical, straight burrows ornamented by widely spaced transverse grooves, which lead, after weathering, to compartmentalisation of the structure resembling rings. The length varies from 29 to $33 \mathrm{~mm}$, and the width from 1.6 to $3.3 \mathrm{~mm}$.

Interpretation and discussion. The presence of the ring-like features presumably reflects the peristaltic movement of the producer, in such a way that the prominence and spacing of the rings are related to the ease and efficiency of feeding the sediment (Pemberton \& Frey, 1982). 
aff. Psammichnites Torell, 1870.

(Fig. 6g)

Material. One specimen preserved as a full relief expressed as a convex epirelief in a layer of micaceous, medium-grained sandstone (VM-1/20).

Description. Horizontal trace with a slightly wavy layout. A smooth, not well defined sinuous axial depression is recognized in the central part of the trace, with a width of $0.7-1 \mathrm{~mm}$. This groove leaves two irregular lobes with an average width of $3.4 \mathrm{~mm}$. The lobes can be also interpreted as discontinuous, each one composed of a series of aligned, somewhat angled lobes. The length of the trace is $62 \mathrm{~mm}$, although a large part of it has been lost due to erosion and is the cause of the poorly marked relief it presents.

Interpretation and discussion. Due to the discontinuity of the lobes and the lack of a well-marked sinusoidal axial furrow, a confident identification of the trace as Psammichnites is not possible. In the absence of a vertical section of the trace, the typical elliptical section and internal arrangement of elements, including a basal meniscate infill and fine transverse striation, characteristics of Psammichnites, are not observed.

The ichnogenus Psammichnites has been interpreted as the result of the sediment disturbance produced by a relatively large, bulldozing, soft-bodied marine organism, probably a flat worm, which moved a few centimetres below the sediment-water interface, parallel to the bedding plane (Gámez-Vintaned et al., 2006). The organism would collect organic detritus from the surface of the sediment with a ciliated snorkel, causing an active filling of the burrow (Seilacher \& Gámez-Vintaned, 1995; Seilacher Drexler \& Seilacher, 1999). The pendular movement of this organ, combined with the anteriorly directed movement of the body would produce the sinuous trace that is observed in the upper levels of the ichnogenus, where the sediment was cut off sharply.

Ichnogenus Rusophycus Hall, 1852

Type ichnospecies Fucoides biloba Vanuxem, 1842

Rusophycus ichnosp. A

(Figs 6f, 6h)

Material. Three specimens preserved as convex hyporeliefs in micaceous, medium to coarse-grained sandstone (VM-1/21-23).

Description. Bilobed trace, shallow, reminiscent of the typical coffee bean shape, although one of the lobes is poorly marked in two of the specimens (VM-1/22 and 23).
The total width of the trace widens slightly backwards, as does the groove of the midline. Width varies between 5.6 and $14.0 \mathrm{~mm}$, and length between 7.2 and $19.5 \mathrm{~mm}$. The width of the groove in its widest part varies between 1.3 and $4.3 \mathrm{~mm}$. The lobes are slightly arched, with a width of 1.6 to $3.8 \mathrm{~mm}$.

No striae or transverse marks are observed, either in the lobes or in the central span.

Interpretation and discussion. Rusophycus is interpreted as a kind of cubichnia, i.e. resting traces (Fillion \& Pickerill, 1990). The absence of ornamentation and the small size of the specimens prevent ichnotaxonomic precisions.

Rusophycus ichnosp. B

(Fig. 6i)

Material. Two specimens preserved as convex hyporeliefs in micaceous, medium to coarse-grained sandstone (VM-1/24-25).

Description. Scarcely marked Rusophycus presenting smoothly convex and rounded lobes that give the specimens a subcircular contour where the values of the width and total length are quite similar, being $35.2 \times 49 \mathrm{~mm}$ in VM-1/24 and $17.4 \times 18.1 \mathrm{~mm}$ in VM-1/25. Consequently, the lobes are relatively wide, varying between $8.9 \mathrm{~mm}$ and $12.3 \mathrm{~mm}$. The median groove is quite narrow and parallel, with values between $1.2 \mathrm{~mm}$ and $6.2 \mathrm{~mm}$. A very thin perpendicular striation is observed in both specimens, at least in one of the lobes, especially in VM-1/24 (left specimen in Fig. 6i).

Interpretation and discussion. The poor preservation of these specimens does not allow us to make ichnotaxonomic precisions in relation to the ichnospecies. Nevertheless, their morphology and slight sculpture do allow considering them as a different ichnospecies as compared to the previous one.

\section{aff. Treptichnus Miller, 1889}

(Fig. 6j)

Material. One specimen preserved as full relief in micaceous, medium to coarse-grained sandstone (VM-1/26).

Description. Subhorizontal burrows with a slightly arched path composed of a series of short segments, somewhat angled, that meet at one of their ends, giving rise to a bifurcation at angles between $10^{\circ}$ and $20^{\circ}$.

Some of these segments show a fine oblique striation at their surface. The entire structure has a length of $31 \mathrm{~mm}$ and is composed of at least 32 segments, which have a length that varies between $2.6 \mathrm{~mm}$ and $5.5 \mathrm{~mm}(3.6 \mathrm{~mm}$ in average) and a width of between $1,3 \mathrm{~mm}$ and $2.2 \mathrm{~mm}$ (average of $1.6 \mathrm{~mm}$ ). 

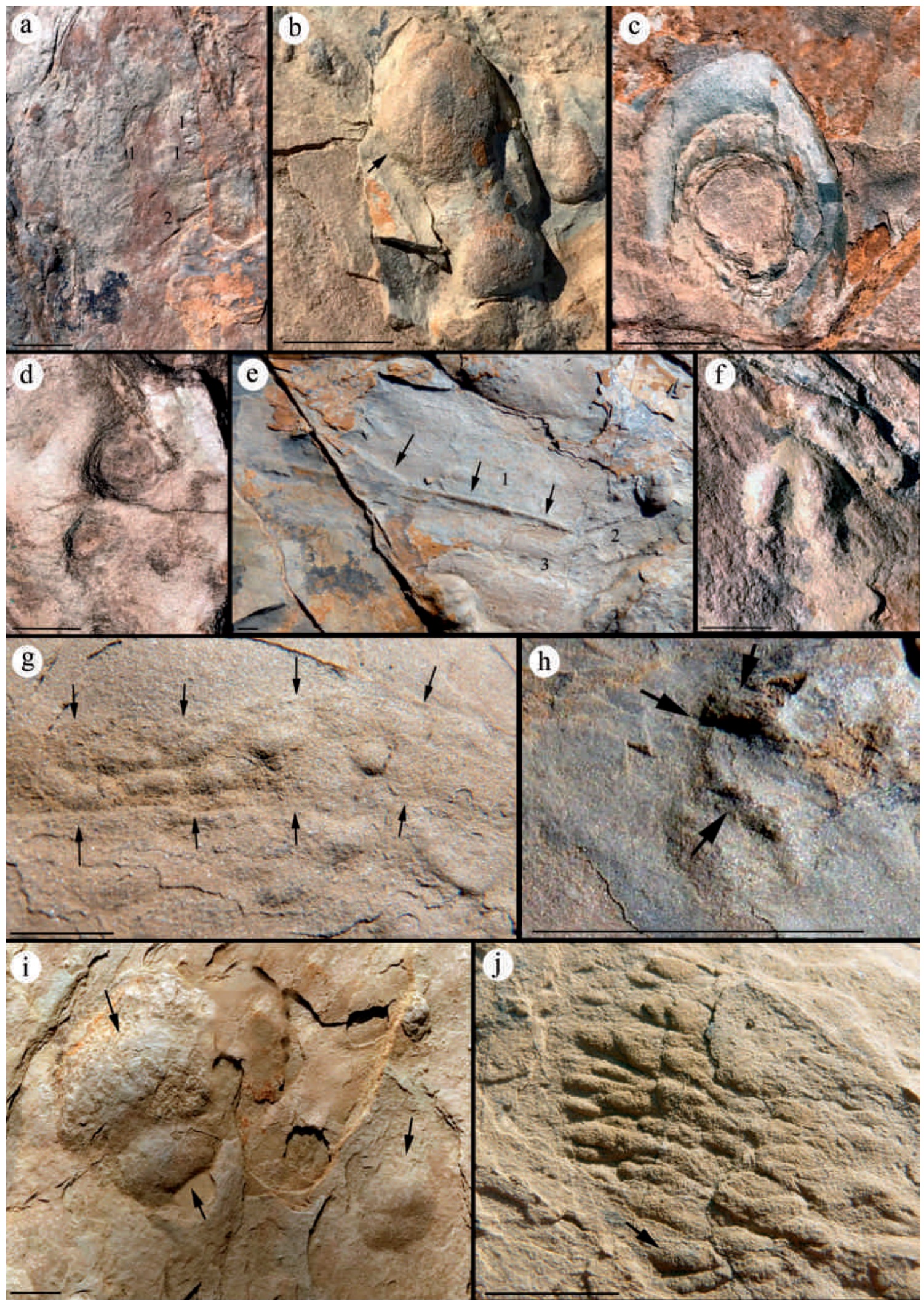

Figure 6. Ichnofossils. a) Diplichnites ichnosp. B (1) and Monomorphichnus ichnosp. indet. (2). b-c) Dolopichnus ichnosp. indet. d) Monocraterion ichnosp. indet. e) Palaeophycus tubularis Hall, 1847 (1). Black arrows show the path of the burrow. Planolites annularis Walcott, 1890 (2) and Monomorphichnus aff. lineatus Crimes, Legg, Marcos \& Arboleya, 1977 (3) are also present. f) Rusophycus ichnosp. A. g) aff. Psammichnites Torell, 1870. Black arrows indicate margins of the trace. h) Rusophycus ichnosp. A. Black arrows point to the lobes. i) Rusophycus ichnosp. B. Lobes are indicated by black arrows. j) aff. Treptichnus Miller, 1889. The arrow points faint striae. All scale bars $=1 \mathrm{~cm}$. 
Interpretation and discussion. This burrow is interpreted as a kind of fodinichnia, made by a sediment-eater organism (Häntzschel, 1975) or as a possible predation or scavenging trace (Vannier et al., 2010), or agricultural trace (Knaust, 2004). It is reminiscent, by its structure and arrangement, to the typical pattern of segments that are arranged in the form of a fan or twisted rope that is characteristic of Treptichnus (Seilacher \& Hemleben, 1966). However, the fact of having found a single specimen, together with its small size, makes its assignment to remain in open nomenclature, waiting for new - and perhaps better - findings.

\section{PALAEOENVIRONMENTAL INTERPRETATION}

The biostratigraphic analysis of the studied post-Visean Carboniferous stratigraphic succession of the Almogía Formation allow to obtain some notions about the palaeoenvironmental conditions of the deposition.

As for the palaeoenvironmental evolution of the Almogía Formation, Martín-Algarra et al. (2004) proposed a transition from channelised turbiditic deposition in proximal or inner submarine fans (lower Retamares Member) to non-channelised turbiditic sedimentation in distal fan facies (upper member).

The degree of fragmentation of the floated plant remains present at Interval I, together with the centimetric size of the xylic fragments, suggests that the latter was deposited in proximal marine (nearshore) settings. The pervasive presence of the ichnotaxon Planolites annularis would support this interpretation. The abundance of microconglomerate in Interval I, as compared to Interval II, together with the absence of plant remains at Interval II, points to an evolution from more proximal to more distal sedimentary settings, i.e., a transgressive trend, throughout the stratigraphic succession. Nevertheless, more data would be perhaps needed in order to confirm this interprtetation to give a more detailed picture of that trend, especially considering the presence of a fault separating Interval I from Interval II.

The presence of skeletal fossils, sometimes showing biostratinomic disarticulation, such as the crinoid stalk plates, but also sporadically including skeletal parts assembled, as shown by the moulds of articulated bivalves (Figs 4a, 4d), together with the two main ichnoassemblages found at the lower part of Interval II, indicate a shallow marine depositional setting. In palaeoecological terms, the palaeoenvironment is interpreted as shallow sublittoral (i.e., infralittoral), with a shallow yet permanent, marine water table of normal salinity under aerobic conditions. Nutrients contents were presumably high, given the types of skeletal fossils found and the variety of benthic life bioturbating the sea bottoms. The total diversity of trace fossils is high, 11 ichnogenera, reflecting the possible presence of few filter-feeder organisms (perhaps the producer organisms of the ichnogenera Monocraterion and Palaeophycus) together with abundant sediment-eaters (namely Dactyloidites, Planolites and aff. Treptichnus) and grazers (Monomorphichnus, aff. Psammichnites and possibly Monocraterion), some predators (seemingly Palaeophycus), several micropredators (Bergaueria and Dolopichnus) and other animals occupying undetermined niches (trilobites producing Diplichnites and Rusophycus).

The two main ichnoassemblages found are representative of the Cruziana ichnofacies, typical of siliciclastic continental shelves. The small differences in the ichnotaxonomic composition of these two ichnoassemblages (Fig. 3) do not reveal any significant palaeoecological dissimilarity. Nevertheless, the upper ichnoassemblage found, located $6.2 \mathrm{~m}$ above the base of Interval II, is differentiated from the lower ichnoassemblage, located $3.5 \mathrm{~m}$ above the base of Interval II, by a slightly bigger presence of traces made by sediment-eaters (fodinichnia) and detritus-eaters (pascichnia), plus the presence of a few traces probably made by predators (horizontal domichnia). The presence of an underlying muddy substrate close to the sandstone recording the upper ichnoassemblage may account for the minor differences reported here between the two ichnoassemblages.

Going further with the palaeoenvironmental interpretation of the upper member of the Almogía Formation, and taking into consideration the markedly different opinion stated herein for our stratigraphic section, as compared to the one given by Mon (1971) and MartínAlgarra et al. (2004) who invoked deep sea facies, it is crucial to note the absence of trace fossils characteristic of the deep sea Nereites ichnofacies. On the contrary, all palaeontological evidence found point to shallow sublittoral (infralittoral) palaeoecological conditions in a siliciclastic continental shelf. Furthermore, a regressive stratigraphic architecture depicted by shelfal materials, occasionally including turbidites (upper member of the Almogía Formation), deposited above relatively deeper facies represented by olistostromes (lower Retamares Member) makes sense in the tectonic setting of basin inversion after the Visean.

\section{CONCLUSIONS}

The observed facies, as well as the lithostratigraphic and biostratigraphic data obtained during our study of the easternmost outcrop of the Maláguide Complex in the Province of Málaga, at its contact with the Benamocarra tectonic unit, together with their comparison with other 
stratigraphic units in the region, allowed us to recognize the upper member of the Almogía Formation in a fossiliferous succession. No age-diagnostic fossils were found, so that the post-Visean Carboniferous age suggested for the Almogía Formation by previous authors is also envisaged in this paper.

The stratigraphic succession has been studied and divided into two intervals. The lower Interval I contains fossil plant remains of Equisetales, probable ferns and centimetric xylic fragments, at several levels interspersed between the prevailing sandstone. The ichnofossil Planolites annularis occurs throughout Interval I and the overlying Interval II. The Interval II has provided a total of eleven ichnogenera and fourteen ichnotaxa, mostly concentrated in two main ichnoassemblages located at the lower part of Interval II: Bergaueria aff. perata, Dactyloidites aff. cabanasi, Diplichnites ichnosp. A, Diplichnites ichnosp. B, Dolopichnus ichnosp. indet., Monocraterion ichnosp. indet., Monomorphichnus aff. lineatus, Monomorphichnus ichnosp. indet., Palaeophycus tubularis, Planolites annularis, aff. Psammichnites, Rusophycus ichnosp. A., Rusophycus ichnosp. B., and aff. Treptichnus. The numerous ichnofossils reflect the activity of annelids, marine anemones, flat worms and arthropods, and they reveal the shallow marine Cruziana ichnofacies. Other fossils present at the level where the uppermost one of the two mentioned main ichnoassemblages occurs are disarticulated crinoid stalks, fragments of trilobites and arcoid bivalves, as well as probable microbial mats.

These are the first Paleozoic fossil assemblages cited in the eastern area of the Province of Málaga. They point to palaeoenvironments of deposition evolving from proximal shallow marine (nearshore; Interval I), up to shallow sublittoral (i.e., infralittoral) in a siliciclastic continental shelf (Interval II). Therefore, previous assumptions on the depositional environments of the upper member of the Almogía Formation should perhaps be reconsidered.

\section{ACKNOWLEDGEMENTS}

We thank professors Francisco Serrano Lozano, University of Málaga, and Francisco Rodríguez-Tovar, University of Granada, for their suggestions. Eduardo Mayoral also acknowledges additional support by Junta de Andalucía through the Research Group RNM 276, and from the Spanish Government through Project CGL2015-66835-P. José Antonio Gámez Vintaned acknowledges support from Universiti Teknologi PETRONAS (Malaysia). With this paper, we pay tribute to Luis Carlos Sánchez de Posada and María Luisa Martínez Chacón for their extensive contributions to the study of the Carboniferous of Spain.

\section{REFERENCES}

Agirrezabala, L.M. \& Gibert, J.M. de 2004. Paleodepth and paleoenvironment of Dactyloidites ottoi (Geinitz 1849) from Lower Cretaceous deltaic deposits (BasqueCantabrian Basin, West Pyrenees). Palaios, 19, 276-291; doi: 10.1669/0883-1351(2004)019<0276:PAPODO $>2.0$ .CO;2.

Alonso Chaves, F.M. \& Orozco, M. 2012. El Complejo Alpujárride de la Axarquía: Zonas de cizalla dúctiles a escala cortical y pliegues recumbentes asociados. Geogaceta, 52, 5-8.

Alpert, S.P. 1973. Bergaueria Prantl (Cambrian and Ordovician), a probable actinian trace fossil. Journal of Paleontology, 47, 919-924.

Alpert, S.P. 1976. Trilobite and star-like trace fossils from the White-Inyo Mountains, California. Journal of Paleontology, 50, 226-239.

Alpert, S.P. \& Moore, J.N. 1975. Lower Cambrian trace fossil evidence for predation on trilobites. Lethaia, 8, 223-230; doi: 10.1111/j.1502-3931.1975.tb00926.x.

Ansell, A.D. \& Trueman, E.R. 1968. The mechanisms of burrowing in the anemone Peachia hastata Gosse. Journal of Experimental Marine Biology and Ecology, 2, 124-134; doi: 10.1016/0022-0981(68)90003-8.

Blumenthal, M.M. 1927. Versuch einer tektonischen Gliederung der betischen Cordilleren von Central- und Südwest-Andalusien. Eclogae Geologicae Helvetiae, 20, 487-532.

Blumenthal, M.M. 1949. Estudio geológico de las cadenas costeras al oeste de Málaga, entre el río Guadalhorce y el río Verde. Boletín del Instituto Geológico y Minero de España, 52, 11-203.

Cabanás, G. 1966. Notas estratigráficas de la provincia de Córdoba. Con una nota sobre un nuevo fósil del Cambriano por Bermudo Meléndez. Notas y Comunicaciones del Instituto Geológico y Minero de España, 90, 77-84.

Crimes, T.P. 1970. Trilobite tracks and other trace fossils from the Upper Cambrian of North Wales. Geological Journal, 7, 47-68; doi: 10.1002/gj.3350070104.

Crimes, T.P., Legg, I., Marcos, A. \& Arboleya, M. 1977. ?Late Precambrian-low Lower Cambrian trace fossils from Spain. In: Trace Fossils 2 (eds. Crimes, T.P. \& Harper, J.C.). Geological Journal, Special Issue, 9, 91-138.

Dawson, J.W. 1873. Impressions and footprints of aquatic animals and markings on Carboniferous rocks. American Journal of Science, 3, 16-24.

Durand Delga, M. 1963. Essai sur la structure des domaines émergés autour de la Méditerranée occidentale. Geologische Rundschau, 53, 534-535.

Elorza, J.J. \& García Dueñas, V. 1981. Mapa Geológico de España a escala 1:50.000. Veléz-Málaga. Instituto Geológico y Minero de España, 58 p., 1 map.

Fillion, D. \& Pickerill, R.K. 1990. Ichnology of the Upper Cambrian? to Lower Ordovician Bell Island and Wabana groups of eastern Newfoundland, Canada. Palaeontographica Canadiana, 7, 119. 
Frey, R. \& Howard, J.D. 1985. Trace fossils from the Panther Member, Star Point Formation (Upper Cretaceous), Coal Creek Canyon, Utah. Journal of Paleontology, 59, 370-404.

Gámez Vintaned, J.A., Liñán, E., Mayoral, E., Dies, M.E., Gozalo, R. \& Muñiz, F. 2006. Trace and soft body fossils from the Pedroche Formation (Ovetian, Lower Cambrian of the Sierra de Córdoba, S. Spain) and their relation to the Pedroche event. Geobios, 39, 443-468; doi: 10.1016/j. geobios.2005.04.004.

Gibert, J.M. de, Martinell, J. \& Domènech, R. 1995. The rosetted feeding trace fossil Dactyloidites ottoi (Geinitz) from the Miocene of Catalonia. Geobios, 28, 769-776; doi: 10.1016/S0016-6995(95)80073-5.

Hall, J. 1847. Paleontology of New York. Vol. 1. C. Van Benthuysen, Albany, 338 p.

Hall, J. 1852. Palaeontology of New York. Vol. 2. C. Van Benthuysen, Albany, $362 \mathrm{p}$.

Hall, J. 1886. Note on some obscure organisms in the roofing slate of Washington County, New York. New York State Museum of Natural History, Report, 39, 1-160.

Häntzschel, W. 1975. Trace fossils and problematica. In: Treatise on Invertebrate Paleontology, Part W, Miscellanea, Supplement I (ed. Teichert, C.). Boulder, Colorado, and Lawrence, Kansas, W1-W269.

Herbig, H.G. 1983. El Carbonifero de las Cordilleras Béticas. $\mathrm{X}$ Congreso Internacional sobre Estratigrafía y Geología del Carbonífero y Pérmico de España, 343-356.

Herbig, H.G. 1984. Reconstruction of a Lost Sedimentary Realm. The limestone boulders in the Carboniferous of the Malaguides (Betic Cordillera, Southern Spain). Facies, $1,1-108$.

Herbig, H.G. \& Mamet, B. 1985. An upper Devonian limestone slide block near Marbella (Betic Cordillera, Southern Spain) and the palaeogeographic relations between Malaguides \& Menorca. Acta Geologica Hispanica, 20, 155-178.

Knaust, D. 2004. Cambro-Ordovician trace fossils from the SW-Norwegian Caledonides. Geological Journal, 39, 1-24; doi: 10.1002/gj.941.

Martín-Algarra, A. (coord.) 2004. Complejo Maláguide. In: Geología de España (ed. Vera, J.A.). Sociedad Geológica de España, Instituto Geológico y Minero de España, 401-410.

Martín-Algarra, A., Rodríguez-Cañero, R., O’Dogherty, L., Sánchez-Navas, A. \& Ruiz-Cruz, M.D. 2004. Complejo Maláguide. Estratigrafía. Paleozoico ¿y más antiguo? (Grupo Piar). In: Geología de España (ed. Vera, J.A.). Sociedad Geológica de España, Instituto Geológico y Minero de España, 401-404.

Miller, S.A. 1889. North American Geology and Paleontology. Western Methodist Book Concern, Cincinnati, OH, 664 p.

Mon, R. 1971. Estudio Geológico del extremo occidental de los Montes de Málaga y de la Sierra de Cártama (Provincia de Málaga). Boletín Geológico y Minero, 82-83, 132-146.

Nicholson, H.A. 1873. Contributions to the study of the errant annelids of the older Palaeozoic rocks. Royal Society of London, Proceeding, 21, 288-290. (Also Geological Magazine, 10, 309-310).
Nicholson H.A. \& Hinde, G.J. 1875. Notes on the fossils of the Clinton, Niagara, and Guelph formations of Ontario, with descriptions of news species. Canadian Journal Sciences, Literature, History, New Series, 14, 137-160.

O’Dogherty, L., Rodríguez-Cañero, R., Gursky, H.J., MartínAlgarra, A. \& Caridroit, M. 2000. New data on Lower Carboniferous Stratigraphy and Palaeogeography of the Malaguide Complex (Betic Cordillera, Southern Spain). Comptes Rendus de l'Académie des Sciences, Series IIAEarth and Planetary Science, 331, 533-541.

Pemberton, S.G. \& Frey, R.W. 1982. Trace fossil nomenclature and the Planolites-Palaeophycus dilemma. Journal of Paleontology, 56, 843-881.

Prantl, F. 1946. Two new problematic trails from the Ordovician of Bohemia. Académie Tchèqe des Sciences, Bulletin International, Classe des Sciences Mathématiques et Naturelles et de la Médcine, 46 (1945), 49-59.

Rodríguez Cañero, R. 1993. Contribución al estudio de los conodontos del Complejo Maláguide (Cordillera Bética). Ph.D. Thesis Universidad de Málaga. 474 p. (unpublished).

Rodríguez Cañero, R. \& Guerra-Merchán, A. 1996. Nuevos datos sobre la fauna de conodontos y la edad de la Formación Falcoña (Complejo Maláguide, Cordillera Bética, España). Revista Española de Paleontología, 11, 235-246.

Ruiz Cruz, M.D. 1997. Very low-grade chlorite with anomalous chemistry and optical properties from the Malaguide Complex, Betic Cordilleras, Spain. The Canadian Mineralogist, 35, 923-935.

Ruiz Cruz, M.D. \& Nieto, J.M. 2002. Condiciones T-P de estabilidad de las fases vermiculíticas en metaclastitas de la zona de Málaga, Cordillera Bética. Boletín de la Sociedad Española de Mineralogía, 25, 95-96.

Seilacher, A. \& Gámez-Vintaned, J.A. 1995. Psammichnites gigas: Ichnological expression of the Cambrian explosion. Proceedings Sixth Paleobenthos International Symposium, Alghero, 28-30 October 1995 (ed. Cherchi, A.). Dipartimento di Scienze della Terra, Università di Cagliari, Cagliari, 151-152.

Seilacher, A. \& Hemleben, C. 1966. Beiträge zur Sedimentation und Fossilführung des Hunsrückschiefers. 14. Spurenfauna und Bildungstiefe der Hunsrückschiefer (Unterdevon). Notizblatt des hessischen Landesamtes für Bodenforschung, 94, 40-53.

Seilacher Drexler, E. \& Seilacher, A. 1999. Undertraces of sea pens, moon snails, and possible fossil counterparts. Neues Jahrbuch für Geologie und Paläontologie, Abhandlungen, 214, 195-210; doi: 10.1127/njgpa/214/1999/195.

Serrano, F. \& Guerra-Merchán, A. 2004. Geología de la Provincia de Málaga. CEDMA (Centro de Ediciones de la Diputación de Málaga), 294 p.

Soedonio, H. 1971. Geological investigations in the Chirivel area, provincia of Almería, South Eastern Spain. Ph.D. Thesis, University Amsterdam, 143 p. (unpublished).

Torell, O.M. 1870. Petrificata Suecana Formationis Cambricae. Acta Universitatis Lundensis, Lunds Universitets Arsskrift, 6, 1-14. 
Tubía, J.M. 1985. Estructura de los Alpujárrides occidentales: cinemática y condiciones de emplazamiento de las peridotitas de Ronda. Boletín Geológico y Minero, 99 $(2,3,4$ y 5$)$.

Vannier, J., Calandra, I., Gaillard, C. \& Zylinska, A. 2010. Priapulid worms: Pioneer horizontal burrowers at the Precambrian-Cambrian boundary. Geology, 38, 711-714; doi: 10.1130/G30829.1.
Vanuxem, L. 1842. Geology of New York. Part III, Comprising the Survey of the Third Geological Fistrict. W. and A. White and J. Visscher, Albany, 306 p.

Walcott, C.D. 1890. Descriptive notes of new genera and species from the Lower Cambrian or Olenellus Zone of North America. US National Museum Proceedings, 12 (1889), 33-46. 
